\title{
CONCISE REPORT
}

\section{Does yttrium radiosynovectomy increase the risk of cancer in patients with rheumatoid arthritis?}

\author{
J Vuorela, T Sokka, E Pukkala, P Hannonen
}

Ann Rheum Dis 2003;62:251-253

Objective: To study the long term risk of cancer in patients with rheumatoid arthritis (RA) who have been treated with yttrium.

Methods: The medical record numbers of 1228 patients with RA who were admitted to hospital in 1979-85 were identified in the database of Jyväskylä Central Hospital. Radiosynovectomy of the knee joint was performed in a total of 143 patients using yttrium-90 silicate during the years 1970-85, while 1075 did not receive yttrium radiosynovectomy; 10 received yttrium treatment later than 1985 and were excluded from the analysis. The Finnish Cancer Registry database was used to examine whether the subjects had cancer during the follow up from 1979 until the end of 1999.

Results: Nine cases of cancer were found among the patients who had received yttrium, whereas the expected number based on the incidence among the population in the region was 14.9 . The standardised incidence ratio of cancer was 0.6 (95\% confidence interval (CI) 0.3 to 1.1$)$ for the patients who received yttrium, and $1.1195 \% \mathrm{Cl} 0.9$ to 1.3) for the patients who did not receive yttrium.

Conclusions: Yttrium treatment did not increase the risk of cancer.

S ynovectomy by radioisotopes has been practised in clinical rheumatology in several countries for almost 50 years, ${ }^{1-4}$ although randomised clinical trials have never proved it to be effective. ${ }^{5}$ The most common target is the chronically inflamed knee joint of a patient with rheumatoid arthritis (RA). Owing to favourable radiation properties and a short half life of 2.7 days, yttrium silicate $\left({ }^{90} \mathrm{Y}\right)$ is the most commonly used agent. Yttrium emits $\beta$ rays only, with a maximum energy of $2.25 \mathrm{MeV}$, and a maximum penetration range in the tissue of $11 \mathrm{~mm}$ (average $3.6 \mathrm{~mm}$ ).

Concerns exist about the potential long term adverse effects of radiation due to possible extra-articular leakage of yttrium to non-target organs like adjacent lymph nodes, liver, lung, and spleen. Chromosomal abnormalities have been found in peripheral lymphocytes after radiosynovectomy..$^{6-9}$ The clinical significance of these changes remains unknown. To our knowledge, no studies of the incidence of cancer in patients who have received intra-articular yttrium injections have been reported.

We aimed at studying the long term risk of cancer in patients with RA who had been treated with yttrium.

\section{PATIENTS AND METHODS}

The medical record numbers of the patients who had a diagnosis code for RA in their discharge summary during years 1979 to 1985 were identified in the database of Jyväskylä Central Hospital. This hospital is the only rheumatology centre in the Central Finland District located in the southern part of
Finland. It serves a population of 263869 (in 2000), which is $5 \%$ of the total population of Finland.

A total of 1228 patients were identified, and their medical records were reviewed. In 143 patients, radiosynovectomy of the knee joint was performed by yttrium during years 1970-85, whereas 1075 patients had never received yttrium. Another 10 patients had been treated with yttrium later than 1985 and were excluded from the analysis. Furthermore, the medical records of another 20 patients were lost or were not available, and the yttrium status of these patients was not known.

Yttrium-90 silicate was injected together with glucocorticoids (mostly triamcinolone hexacetonide) and lidocaine. The mean dose of radioactive yttrium was $185 \mathrm{MBq}$. Patients were immobilised and kept in bed for three days after yttrium injection. An earlier study from our centre showed that in patients treated according to this procedure the radiation doses in the inguinal lymph nodes ranged from 0 to $9.20 \mathrm{~Gy}{ }^{6}$

The vital status of the subjects was achieved from a database of the Population Register Centre of Finland according to personal identification numbers, which have been used in all main registers in Finland since 1967. The Finnish Cancer Registry database was used to examine whether the subjects had cancer.

Follow up for cancer started at the date of the first admission to hospital during 1979-85 or on the date of the first yttrium treatment, whichever was later, and ended at death or on 31 December 1999, whichever was first. The numbers of observed cases and person-years at risk were calculated for the follow up period. The expected numbers of cases for total cancer and for specific cancer types were calculated by multiplying the number of person-years in each sex and age category by the corresponding average cancer incidence in the Central Finland District during the respective calendar period of observation. To calculate the standardised incidence ratio (SIR), the observed number of cases was divided by the expected number. The 95\% confidence intervals (CI) for the SIR were based on the assumption that the number of observed cases followed a Poisson distribution.

The ethics committee of Jyväskylä Central Hospital and the Ministry of Social Affairs and Health of Finland approved the study.

\section{RESULTS}

A total of 332 men and 886 women were followed up in the cohort with 4045 and 12185 person-years, respectively (table 1). The mean length of follow up was 13.3 years.

During the follow up period, nine cases of cancer were diagnosed in patients who received yttrium; the expected number was 14.9. In addition to the six cancer cases, which

Abbreviations: $\mathrm{Cl}$, confidence interval; RA, rheumatoid arthritis; SIR, standardised incidence ratio 
Table 1 Number of patients with rheumatoid arthritis receiving follow up (n), and number of person-years at risk in 1979-99, by treatment, sex, and age

\begin{tabular}{|c|c|c|c|c|c|c|c|c|}
\hline \multirow[b]{3}{*}{ Age, years } & \multicolumn{4}{|c|}{ Yttrium } & \multicolumn{4}{|c|}{ No yttrium } \\
\hline & \multicolumn{2}{|c|}{ Men } & \multicolumn{2}{|c|}{ Women } & \multicolumn{2}{|l|}{ Men } & \multicolumn{2}{|c|}{ Women } \\
\hline & $\mathrm{n}^{*}$ & $\begin{array}{l}\text { Person- } \\
\text { years }\end{array}$ & $\mathrm{n}^{*}$ & $\begin{array}{l}\text { Person- } \\
\text { years }\end{array}$ & $\mathrm{n}^{*}$ & $\begin{array}{l}\text { Person- } \\
\text { years }\end{array}$ & $\mathrm{n}^{*}$ & $\begin{array}{l}\text { Person- } \\
\text { years }\end{array}$ \\
\hline$<30$ & & & & & 17 & 119 & 55 & 324 \\
\hline $30-44$ & 1 & 2 & 5 & 26 & 47 & 461 & 168 & 1733 \\
\hline $45-59$ & 15 & 91 & 45 & 331 & 120 & 1226 & 270 & 3603 \\
\hline $60-74$ & 18 & 140 & 52 & 661 & 104 & 1557 & 236 & 3937 \\
\hline $75+$ & 2 & 69 & 5 & 228 & 8 & 380 & 50 & 1342 \\
\hline Total & 36 & 302 & 107 & 1246 & 296 & 3743 & 779 & 10939 \\
\hline
\end{tabular}

Table 2 Observed (Obs) and expected (Exp) numbers of specific cancer cases and standardised incidence ratios (SIR) with 95\% confidence intervals $(\mathrm{Cl})$ among patients with rheumatoid arthritis in 1979-99, by treatment and cancer site

\begin{tabular}{|c|c|c|c|c|c|c|c|c|}
\hline \multirow[b]{2}{*}{ Site } & \multicolumn{4}{|c|}{ Yttrium } & \multicolumn{4}{|c|}{ No yttrium } \\
\hline & Obs & Exp & SIR & $95 \% \mathrm{Cl}$ & Obs & Exp & SIR & $95 \% \mathrm{Cl}$ \\
\hline Stomach & 1 & 0.9 & 1.1 & 0.03 to 6.1 & 8 & 6.3 & 1.3 & 0.6 to 2.5 \\
\hline Colon, rectum & 3 & 1.6 & 1.9 & 0.4 to 5.6 & 12 & 11.2 & 1.1 & 0.6 to 1.9 \\
\hline Liver & 0 & 0.1 & 0.0 & 0.0 to 27 & 1 & 1.0 & 1.1 & 0.03 to 5.8 \\
\hline Lung, bronchus & 1 & 1.4 & 0.7 & 0.02 to 4.0 & 17 & 11.0 & 1.5 & 0.9 to 2.5 \\
\hline Breast & 0 & 2.4 & 0.0 & 0.0 to 1.5 & 20 & 18.5 & 1.1 & 0.7 to 1.7 \\
\hline $\begin{array}{l}\text { Non-Hodgkin's lymphoma } \\
\text { (nodal) }\end{array}$ & 0 & 0.3 & 0.0 & 0.0 to 11 & 6 & 2.4 & 2.5 & 0.9 to 5.4 \\
\hline Hodgkin's lymphoma & 0 & 0.1 & 0.0 & 0.0 to 79 & 0 & 0.4 & 0.0 & 0.0 to 9.7 \\
\hline Myeloma & 0 & 0.3 & 0.0 & 0.0 to 15 & 2 & 1.8 & 1.1 & 0.1 to 4.1 \\
\hline Leukaemia & 1 & 0.3 & 2.9 & 0.07 to 16 & 1 & 2.4 & 0.4 & 0.01 to 2.3 \\
\hline
\end{tabular}

Table 3 Observed and expected numbers of cancer cases, and the standardised incidence ratios (SIR) with $95 \%$ confidence intervals (CI) among patients with rheumatoid arthritis in 1979-99, by treatment and age

\begin{tabular}{|c|c|c|c|c|c|c|c|c|}
\hline \multirow[b]{2}{*}{ Age, years } & \multicolumn{4}{|l|}{ Yttrium } & \multicolumn{4}{|l|}{ No yttrium } \\
\hline & Observed & Expected & SIR & $95 \% \mathrm{Cl}$ & Observed & Expected & SIR & $95 \% \mathrm{Cl}$ \\
\hline$<60$ & 2 & 1.9 & 1.1 & 0.1 to 3.9 & 24 & 23.4 & 1.0 & 0.7 to 1.5 \\
\hline $60-74$ & 6 & 7.7 & 0.8 & 0.3 to 1.7 & 65 & 54.8 & 1.2 & 0.9 to 1.5 \\
\hline $75+$ & 1 & 5.3 & 0.2 & 0.0 to 1.0 & 33 & 30.8 & 1.1 & 0.7 to 1.5 \\
\hline Total & 9 & 14.9 & 0.6 & 0.3 to 1.1 & 122 & 108.9 & 1.1 & 0.9 to 1.3 \\
\hline
\end{tabular}

are listed in table 2, the other three were one soft tissue sarcoma, one squamous cell carcinoma of the skin, and one ovarian adenocarcinoma. In patients who did not receive yttrium, 122 cases of cancer were diagnosed while the expected number was 109. Neither the total cancer SIR of 0.6 (95\% CI 0.3 to 1.1 ) for the patients who received yttrium nor the SIR of 1.1 (95\% CI 0.9 to 1.3 ) for the patients who did not receive yttrium, were statistically significantly different from cancer incidence in the background population of the Central Finland District (table 3), or from each other: the ratio of $\mathrm{SIR}_{\text {Ytrium }} / \mathrm{SIR}_{\text {Non-ytrium }}$ was 0.5 (95\% CI 0.2 to 1.1$)$.

The SIRs for non-Hodgkin lymphoma and lung cancer were raised among the patients who did not receive yttrium, but the SIRs were not statistically significantly different from those of the population (table 2 ).

\section{DISCUSSION}

The main finding of this study is that the total incidence of cancer did not increase in patients with RA who were treated with yttrium. In fact, patients who received yttrium had a low SIR of 0.6 , which may well be explained by chance owing to a small sample size.

A recent systematic review questioned whether yttrium synovectomy deserves a place in clinical practice because evidence of efficacy is lacking. ${ }^{5}$ However, only two randomised controlled clinical trials ${ }^{10}{ }^{11}$ met the inclusion criteria to be reviewed. Nevertheless, based on clinical experience, yttrium synovectomy is beneficial in properly selected patients, ${ }^{12}$ and in certain countries it is still widely used.

Yttrium synovectomy has potential long term effects of radiation exposure such as cancer. The concerns are mostly based on observed chromosomal abnormalities in peripheral lymphocytes after radiosynovectomy. ${ }^{6-9}$ However, the latency period before development of a cancer lasts for years in the case of small doses of radiation. Risk of leukaemia is estimated to be greatest 5-10 years after the exposure, whereas the risk of solid tumours increases during the rest of the lifespan..$^{13}$ The observation period of up to 30 years in our study appears to be 
sufficient to confirm that yttrium synovectomy is also safe in the long term.

Several previous studies have shown that patients with RA have an increased risk for cancers of haematopoietic and lymphatic tissue $e^{14-25}$ but a decreased risk for cancers of the colon and stomach. ${ }^{20}{ }^{23-26}$ In the present study the SIR for lung cancer of patients who did not receive yttrium was 1.5, and for non-Hodgkin's lymphoma 2.5. These findings did not quite reach statistical significance, but are in line with the previous reports.

Although the present cohort consisted entirely of patients admitted to hospital during 1979-85 with a diagnosis of RA, the study was still small, which is one of its limitations. For all except 20 patients the hospital records were traced and yttrium treatment could be identified. The identification of cohort members and follow up for deaths was complete for the period of this study. Cancer registration system in Finland is virtually complete ${ }^{27}$ and the computerised record linkage procedure is precise..$^{28}$ Therefore, technical incompleteness should not have caused a bias in the results.

Another concern is a possible bias in the overall disease activity, disease duration, and comorbidity of patients selected for yttrium treatment. Patients who received yttrium in all age groups (according to table 1) had longer duration of disease than the non-receivers (data not shown). Longer duration of disease is associated with a greater cumulative burden of the disease. Therefore, the bias in patient selection for yttrium treatment would have suggested that patients treated with yttrium might have greater risk for cancer. However, despite longer disease duration, the risk of cancer was not increased in patients who were treated with yttrium.

In conclusion, the incidence of cancer was not increased over a period of 30 years after yttrium treatment. More data on the long term effects of yttrium treatment can only be achieved by combining cohorts of yttrium treated patients from several centres with reliable databases.

\section{ACKNOWLEDGEMENTS}

The authors thank Professor Ahti Rekonen for helpful discussions throughout the manuscript preparation, Ms Sari Leinonen and Mr Tuukka Tarkiainen for excellent data management, and research analysts Melissa Gibson and Christopher Swearingen for revision of the English of the manuscript.

Supported in part by Keski-Suomen Syöpäyhdistys.

\section{Authors' affiliations}

J Vuorela, Hospital Physics, Jyväskylä Central Hospital, Jyväskylä, Finland

T Sokka, Department of Medicine, Jyväskylä Central Hospital, Jyväskylä, Finland and Vanderbilt University, Nashville, TN, USA

P Hannonen, Department of Medicine, Jyväskylä Central Hospital, Jyväskylä, Finland

E Pukkala, Finnish Cancer Registry, Institute for Statistical and Epidemiological Cancer Research, Helsinki, Finland

Correspondence to: Dr T Sokka, Vanderbilt University/Rheumatology, 203 Oxford House, Nashville TN 37232-4500, USA; tuulikki.sokka@vanderbilt.edu

Accepted 9 July 2002

\section{REFERENCES}

1 Fellinger K, Schmid J. Die Lokale Behandlung der rheumatischen Erkrankung (Local therapy of rheumatoid arthritis). Wien Ztsch Inn Med 1952;33:351
2 Oka M, Rekonen A, Ruotsi A, Seppälä O. Intra-articular injection of Y-90 resin colloid in the treatment of rheumatoid knee joint effusions. Acta Rheumatol Scand 1971;17:148-59.

3 Rau R, Schutte H. (Results of radiosynoviorthesis with yttrium 90 in chronic synovitis: a long-term prospective study. I. Total results and effect of local factors). Z Rheumatol 1983;42:265-70.

4 Franke C. (Value of radiosynovectomy in rheumatology and orthopedics). Schweiz Med Wochenschr 2000;130:77-83.

5 Heuft-Dorenbosch LL, de Vet HC, van der Linden S. Yttrium radiosynoviorthesis in the treatment of knee arthritis in rheumatoid arthritis: a systematic review. Ann Rheum Dis 2000;59:583-6.

6 de la Chapelle A, Rekonen A, Oka M, Ruotsi A. Chromosome damage after intra-articular injections of radioactive yttrium. Effect of immobilization on the biological dose. Ann Rheum Dis 1972;31:508-12.

7 Prosser JS, Izard BE, Brown JK, Hetherington EL, Lambrecht RM, Cato L, et al. Induction of micronuclei in peripheral blood lymphocytes of patients treated for rheumatoid or osteo-arthritis of the knee with dysprosium-165 hydroxide macroaggregates or yttrium-90 silicate. Cytobios 1993;73:7-15.

8 Stevenson AC, Bedford J, Dolphin GW, Purrott RJ, Lloyd DC, Hill AG, et al. Cytogenetic and scanning study of patients receiving intra-articular injections of gold-198 and yttrium-90. Ann Rheum Dis 1973;32:112-23.

9 Dolphin GW. Biological hazards of radiation. Ann Rheum Dis 1973;32:23

10 Bridgman JF, Bruckner F, Eisen V, Tucker A, Bleehen NM. Irradiation of the synovium in the treatment of rheumatoid arthritis. Q J Med 1973:42:357-67.

11 Grant EN, Bellamy N, Fryday-Field K, Dinsey T, Driedger A, Hobby K, et al. Double-blind randomized controlled trial and six-year open follow up of yttrium-90 radiosynovectomy versus triamcinolone hexacetonide in persistent rheumatoid knee synovitis. Inflammopharmacology 1992; 1:231-8

12 Sholter D, Davis P. Radiochemical synovectomy. Scand J Rheumatol 1997:26:337-41

13 UNSCEAR. Sources and effects of ionizing radiation. UNSCEAR 1994 Report to the General Assembly, with scientific annexes. New York: United Nations, 1994.

14 Isomäki HA, Hakulinen T, Joutsenlahti U. Excess risk of lymphomas, leukemia and myeloma in patients with rheumatoid arthritis. J Chron Dis 1978;31:691-6.

15 Hakulinen T, Isomäki HA, Knekt P. Multiple tumor incidence in patients with rheumatoid arthritis or allied disorders. J Chronic Dis 1985;38:775-9.

16 Prior P. Cancer and rheumatoid arthritis: epidemiologic considerations. Am J Med 1985;78:15-21.

17 Hakulinen T, Isomäki $H$, Knekt P. Rheumatoid arthritis and cancer studies based on linking natiowide registries in Finland. Am J Med 1985;78(suppl 1A):29-32.

18 Laakso M, Mutru O, Isomäki H, Koota K. Cancer mortality in patients with rheumatoid arthritis. J Rheumatol 1986;13:522-6.

19 Silman AJ, Petrie J, Hazleman B, Evans SJ. Lymphoproliferative cancer and other malignancy in patients with rheumatoid arthritis treated with azathioprine: a 20 year follow up study. Ann Rheum Dis 1988:47:988-92

20 Gridley G, McLaughlin JK, Ekbom A, Klareskog L, Adami HO, Hacker DG, et al. Incidence of cancer among patients with rheumatoid arthritis. J Natl Cancer Inst 1993;85:307-1 1.

21 Myllykangas-Luosujärvi R, Aho K, Isomäki H. Mortality from cancer in patients with rheumatoid arthritis. Scand J Rheumatol 1995;24:76-8.

22 Bendix G, Bielle A, Holmberg E. Cancer morbidity in rheumatoid arthritis patients treated with Proresid or parenteral gold. Scand J Rheumatol $1995 ; 24: 79-84$

23 Mellemkjaer L, Linet MS, Gridley G, Frisch M, Moller H, Olsen JH. Rheumatoid arthritis and cancer risk. Eur J Cancer 1996;32A: 1753-7.

24 Cibere J, Sibley J, Haga M. Rheumatoid arthritis and the risk of malignancy. Arthritis Rheum 1997;40:1580-6.

25 Thomas E, Brewster DH, Black RJ, Macfarlane GJ. Risk of malignancy among patients with rheumatic conditions. Int J Cancer 2000;88:497-502.

26 Kauppi $M$, Pukkala $E$, Isomäki $H$. Low incidence of colorectal cancer in patients with rheumatoid arthritis. Clin Exp Rheumatol 1996;14:551-3.

27 Teppo L, Pukkala E, Lehtonen M. Data quality and quality control of a population-based cancer registry. Experience in Finland. Acta Oncol 1994;33:365-9.

28 Pukkala E. Use of record linkage in small-area studies. In: Elliot P Guzick J, English D, Stern R, eds. Geographical and environmental epidemiology. Oxford: Oxford University Press, 1992:125-31. 